
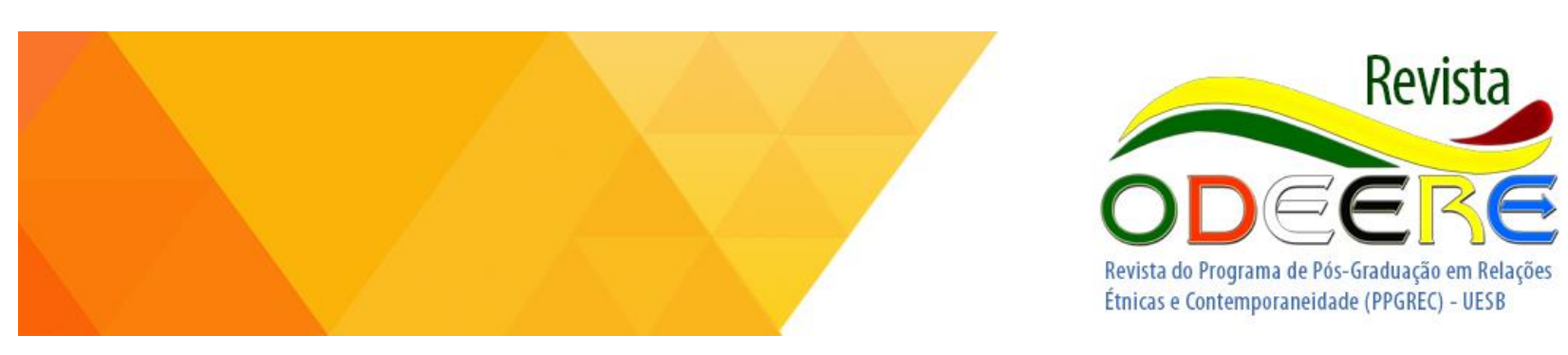

\section{O samba-reggae:} uma afirmação do sagrado, cultural e político

\author{
Roberta Rosa Portugal \\ Universidade Estadual da Paraíba (UEPB) \\ robertauefs@gmail.com
}

DOI: https://doi.org/10.22481/odeere.v3i3.1582
Resumo: O tema deste estudo é o ritmo samba-reggae como uma expressão afrobrasileira. Apresentamos, inicialmente, alguns aspectos sócio históricos relevantes no tocante à construção da multietnismo e multilinguismo na Bahia, para que se possa compreender tal ritmo como expressão afro. Como corpus de análise apresentamos algumas composições musicais do ritmo citado, que foram examinadas a partir de uma perspectiva léxico semântica, com o objetivo de assinalar sua conexão com aspectos afro religioso e afro político.

Palavras-Chave: Samba-Reggae, Sagrado, Línguas Africanas.

Samba-reggae: an affirmation of the sacred, cultural and political

Abstract: The present study has as theme the samba-reggae rhythm as an Afro-Brazilian expression. We present, initially, some relevant socio-historical aspects that are relevant to the multi ethnicism and multilingualism in Bahia, thus it can be possible to comprehend such rhythm as an Afro expression. Concerning the corpus of analysis we present some musical compositions from the mentioned rhythm, which were analyzed from a lexical-semantic perspective, having the scope of marking its connection with Afro religious and Afro political aspects. 
Keywords: Samba-Reggae, Sacred, African Languages.

\section{Multietnismo e multilinguismo do Brasil}

As primeiras décadas do período colonial no Brasil são marcadas pela presença de povos autóctones e pela chegada de outros povos, ocasionando o contato entre diferentes etnias. Segundo Araújo, a "presença indígena no Brasil colonial foi marcante, pois, dada a superioridade numérica dos indígenas, os portugueses tiveram de aprender a língua dos tupinambás, ocorrendo uma situação de bilinguismo"1". A chegada dos portugueses, o processo de colonização e exploração territorial proporcionou a exploração de povos africanos, afirmando a relação de escravismo e de contato com línguas africanas no Brasil. Para esse autor, os africanos, oficialmente desde 1549, data que coincide com a oficialização do tráfico negreiro, atua como "base da formação da nação brasileira".

Este processo de colonização trouxe, por meio do tráfico negreiro, povos de diferentes regiões africanas, pertencentes a diferentes culturas. A presença de povos africanos no Brasil é decisiva na construção de aspectos linguísticos e culturais, sobretudo na Bahia, onde são perceptíveis a influência da religião de origem africana, o candomblé, e o uso de termos africanos, em sua maioria, banto e iorubá nos rituais religiosos e nos ritmos musicais. É neste contexto sócio histórico que se forma, no Brasil, um cenário de multietnismo e multilinguismo.

Os aspectos sócio históricos que caracterizam uma sociedade constroem a sua identidade. A cultura baiana é o resultado da mescla de diferentes culturas, de línguas diversas, em especial, africanas, que se fazem muito presentes na religião, na música e na linguagem. Os africanos, segundo Araújo, tem uma forte responsabilidade na formação do português brasileiro:

\footnotetext{
${ }^{1}$ ARAÚJO, Silvana Silva de Farias; ARAÚJO, Jean Marcel de Oliveira. A formação sócio-histórica do português do brasil: contribuições do recôncavo baiano. In: Cadernos de Letras da UFF - Dossiê: Difusão da língua portuguesa. Rio de Janeiro: UFF, n. 39, p. 95-116, 2009, p.97.

${ }^{2}$ ARAÚJO, Silvana Silva de Farias; ARAÚJO, Jean Marcel de Oliveira. A formação sócio-histórica do português do brasil: contribuições do recôncavo baiano. In: Cadernos de Letras da UFF - Dossiê: Difusão da língua portuguesa. Rio de Janeiro: UFF, n. 39, p. 95-116, 2009, p.98.
}

Odeere: revista do programa de pós-graduação em Relações Étnicas e Contemporaneidade - UESB. ISSN 2525- 4715. Ano 2, número 3, volume 3, Janeiro - Junho de 2017. 
Assim, ao contrário do que ocorreu com a população autóctone, os africanos e afro-descendentes estiveram na base da pirâmide populacional brasileira, entre os séculos XVII e XIX, de modo que a maneira como eles falavam contribuiu bastante para dar uma feição brasileira à língua portuguesa ${ }^{3}$.

A maioria dos africanos trazidos à Bahia ficou conhecida como congo e angola (povo banto) e nagô (povo iorubá). A chegada do povo banto na Bahia é registrada no século XVII e a do povo iorubá no século XIX. Segundo Pessoa de Castro (2005), através de seus estudos sobre língua portuguesa no Brasil e linguagem religiosa do candomblé, os aportes lexicais podem ser classificados em antigos e contemporâneos: antigos são aqueles que já estão totalmente incorporados ao português popular brasileiro, em sua maioria de origem banto, como, por exemplo, os termos que nomeiam instrumentos musicais, palavras utilizados para flora, fauna e também na religião; os contemporâneos, maioria precedente da linguagem religiosa, são aqueles que tem notoriedade, principalmente, por conta do prestígio de alguns terreiros de candomblé e um maior acesso a cursos de iorubá.

Aqui, devemos destacar as importações do iorubá, língua que há mais de trinta anos vem sendo ensinada em várias partes do Brasil e que tem visto publicações em português. Também, e não tão recente a entrada sucessiva, no mercado fonográfico, de compositores pertencentes ao terreiros-de-queto, e que terminam por divulgar o nome dos orixás e termo tirados da língua-de-santo, apelidada de nagô. A palavra axé, como vimos, atravessou os limites dos terreiros, para ser popularizada como saudação votiva, equivalente a amém, "boa sorte", e, por fim, denominar um estilo de música recriado na Bahia, a "axémusic". $^{4 \prime}$

Guimarães (2005) coloca a língua como uma unidade histórica individualizadora de grupos sociais, posto que não se desprende deles. Por questões históricas, em virtude das relações sociais que são estabelecidas entre os seus falantes, as línguas passam por processos de alterações. Com as relações de contato da língua portuguesa com outras línguas, como as indígenas e, principalmente, as africanas, o português falado no Brasil apresenta elementos

\footnotetext{
${ }^{3}$ ARAÚJO, Silvana Silva de Farias; ARAÚJO, Jean Marcel de Oliveira. A formação sócio-histórica do português do brasil: contribuições do recôncavo baiano. In: Cadernos de Letras da UFF - Dossiê: Difusão da língua portuguesa. Rio de Janeiro: UFF, n. 39, p. 95-116, 2009, p.99.

${ }^{4}$ PESSOA DE CASTRO, Yeda. Falares africanos na Bahia: um vocabulário afro-brasileiro. 2 ed. Rio de Janeiro: Topbooks, 2005, p. 121.
} 
fonéticos, lexicais e semânticos particulares. O contato entre diferentes etnias provocou um quadro de transfigurações culturais, como afirma Diégues Júnior:

Não puderam os escravos negros manter íntegra sua cultura, nem utilizar preferentemente suas técnicas em relação ao novo meio. Não foi possível aos negros revelarem e aplicarem todo o seu conjunto cultural: ou porque, ao contato com outros grupos negros, receberam ou perderam certos elementos culturais, ou porque, como escravos, tiveram sua cultura deturpada. Daí os sincretismos e os processos transculturativos ${ }^{5}$.

Os traços culturais dos africanos escravizados no Brasil se revelam na expressividade da religião, da capoeira, da música e da dança mostrando a existência e a resistência dessas culturas. Verger (1992) coloca que os africanos escravizados no Brasil pertenciam a distintos grupos étnicos, que falavam línguas diversas e seguiam diferentes tradições religiosas, porém estavam identicamente submetidos à escravidão e às convicções religiosas dos europeus. Os portugueses justificavam a dança e os cânticos dos africanos como uma ação nostálgica, sem saber que eram preces aos seus orixás, como diz Verger:

Quando precisavam justificar o sentido dos seus cantos, os escravos declaravam que louvavam na sua língua, os santos do paraíso. Na verdade, o que eles pediam era a ajuda e proteção aos seus próprios Deuses ${ }^{6}$.

Segundo Verger (1992), os escravos, quando se reuniam, utilizavam os santos do catolicismo, representando seus orixás, com o intuito de fazer parecer a seus senhores que eles tinham fé católica. O fato dos senhores não conhecerem com detalhes as tradições religiosas dos escravos, facilitava a associação de entidades católicas e africanas.

O candomblé é um conjunto de fazeres e saberes que afirma e valoriza as crenças e rituais que mantêm viva a memória e a história de povos e deuses africanos. Por conta do multietnismo marcante na formação do Brasil, o candomblé não pode ser visto como uma religião pura, pois foi atravessado por outras religiões. Por esta razão o candomblé pode

\footnotetext{
${ }^{5}$ DIÉGUES JÚNIOR, Manuel. Etnias e culturas no Brasil. Rio de Janeiro: Biblioteca do Exército, 1980, p. 100.

${ }^{6}$ VERGER, Pierre Fatumbi. Orixás. 4 ed. São Paulo: Corrupio Edições e Promoções Culturais, 1992, p. 26.
} 
apresentar características diferentes que estarão condicionadas à região onde se localiza, aos costumes e às línguas de cada nação religiosa.

Para a etnolinguísta Pessoa de Castro (2005) as religiões afro-brasileiras são organizações sócio religiosas baseadas em crenças e tradições comuns. Estas organizações do candomblé são divididas em nações de procedência africana diferentes: nação jeje-mina, nagôqueto ou congo-angola, que se caracterizam pela utilização de um repertório linguístico específico. A linguagem litúrgica da nação jeje-mina caracteriza-se pela predominância de termos de base ewe-fon, a nação nagô-queto por termos de base iorubá e a nação congo-angola por termos de base banto.

As religiões afro-brasileiras nascidas na escravidão e genericamente chamadas de candomblé na Bahia, xangô em Pernambuco e tambor no Maranhão, cada qual é um tipo de organização sócio-religiosa baseada em padrões comuns de tradições africanas, em um sistema de crenças, modo de adoração e língua ${ }^{7}$.

Pessoa de Castro (2005) discorre sobre a participação das línguas africanas no português brasileiro e explica que a falta de informações linguísticas precisas limita as pesquisas neste campo, provocando erros relacionados à origem dos vocábulos. Ao tratar sobre povos e línguas africanas no Brasil, a pesquisadora registra a presença do povo banto e dos oeste-africanos na formação cultural brasileira. Segundo ela, há grandes dificuldades em precisar a origem do povo banto, pois sua procedência está sempre relacionada aos portos onde embarcou. Registra-se sua chegada no século XVII, ficando conhecidos como congos e angolas. Entre eles os que mais tiveram contato com os portugueses foram os bacongo, ambundo e ovibundo, falantes, respectivamente, das línguas quicongo, quimbundo e umbundo, sendo as duas primeiras as mais expressivas no candomblé Nação Congo-Angola da Bahia. Entre os povos oeste-africanos chegados ao Brasil, destacam-se os falantes de línguas ewe-fon, que estiveram presentes na Bahia e em outras regiões do Brasil no final do século XVII, e falantes de iorubá, que ficaram conhecidos como nagôs ao chegarem à Bahia no século XIX, em 1830, devido a destruição do império Oyó. A pesquisadora, ao dissertar sobre a língua iorubá, afirma que esta é composta por falares regionais semelhantes, geograficamente situados entre a Nigéria Ocidental e o Reino de Queto, no Benim

\footnotetext{
${ }^{7}$ PESSOA DE CASTRO, Yeda. Falares africanos na Bahia: um vocabulário afro-brasileiro. 2 ed. Rio de Janeiro: Topbooks, 2005, p. 80.
}

Odeere: revista do programa de pós-graduação em Relações Étnicas e Contemporaneidade - UESB. ISSN 2525- 4715. Ano 2, número 3, volume 3, Janeiro - Junho de 2017. 
Oriental. Em Salvador, no século XVII, já havia a presença de povos de origem banto, família lingüística mais incorporada ao português popular brasileiro, sendo que a influência iorubá passou a ser registrada somente a partir do século XIX, segundo Pessoa de Castro (2005), que também registra a relevância destes povos na elaboração do conjunto de crenças, rituais religiosos e cânticos que caracterizam o candomblé. Esses elementos africanos, lingüísticos e religiosos, estão presentes também na música de expressão negra criada na Bahia, o samba-reggae, tema da discussão ora formulada.

Vale registrar que outros povos oeste-africanos também foram escravizados na Bahia, como, por exemplo, os africanos do grupo linguístico ewe-fon, nupe e haúça, sendo que os indivíduos falantes desta última língua e os nagôs participaram da revolta dos malês, em Salvador, em 1835. Também foi registrada a presença de outros povos do Atlântico-Ocidental, na cidade de Salvador, no século XIX, falantes da família linguística fulani e grunce, conforme Pessoa de Castro (2005). No início do século XX, ainda registra-se a presença de iorubafones em Salvador. O fato deste registro ser recente talvez tenha contribuído para a grande incidência de vocábulos iorubá utilizados na linguagem popular baiana e na linguagem do povo-de-santo da nação-queto, na contemporaneidade.

Postas estas considerações sobre o cenário linguístico brasileiro, sigamos com nossas reflexões sobre o samba reggae, que, em nossa visão, é um lugar para afirmar o caráter simbólico das línguas negras.

\section{O samba reggae: o sagrado e o profano na música afro baiana}

As letras de músicas de samba-reggae - ritmo tipicamente baiano - refletem a necessidade de afirmar a expressividade da cultura negra. As composições popularizam termos de origem africana utilizados nos rituais religiosos e se impõem como um ato político.

Pessoa de Castro afirma que o português popular da Bahia apresenta forte influência de línguas africanas, em vários âmbitos culturais como, por exemplo, na religião e na música: “A palavra axé, como vimos, atravessou os limites dos terreiros, para ser popularizada como 
saudação votiva, equivalente a amém, "boa sorte", e, por fim, denominar um estilo de música recriada na Bahia, a axé-music ${ }^{8 \prime \prime}$.

No Brasil, a influência africana é notada em vários aspectos culturais, como, por exemplo, na música popular brasileira, pois vários ritmos musicais como o samba, o maracatu, são ritmos de raízes africanas. Na Bahia, o elemento negro se faz muito presente, pois este estado recebeu um grande contingente de escravos e é o estado de maior população negra no Brasil. A expressividade do candomblé na Bahia e toda música aí produzida mostram a significativa participação das nações congo-angola (banto) e nagô-queto (iorubá) na cultura do estado. Pessoa de Castro (2005) e o compositor Martinho da Vila (2007) citam a participação de culturas africanas na música baiana, nomeando-a de axé-music.

Pessoa de Castro, como etnolinguista, preocupa-se com aspectos linguísticos, com o léxico, seus valores semânticos e suas origens africanas. Martinho da Vila, como cantor e compositor, ao escrever sobre a música popular brasileira, em seu texto "A influência africana na música popular", preocupa-se com a diversidade cultural que a caracteriza. Estes dois autores nomeiam a música popular baiana como axé-music, sem preocupação em delimitar o que seria o samba-reggae nesta perspectiva. Para Goli Guerreiro (2000), o samba-reggae é o estilo musical que resulta da união entre o samba e o reggae jamaicano. Para a autora "além do encontro das sonoridades percussivas e harmônicas, os blocos de trio elétrico gravavam as canções dos blocos afro, carregadas de conteúdo anti-racista, produzindo uma espécie de samba-reggae pop/eletrônico"'.

O samba-reggae, segundo Guerreiro, provocou uma efervescência musical em Salvador, que se espalhou pelo resto do Brasil:

Em 88, a mídia anunciava que em Salvador os blocos afro haviam inventado o samba-reggae, um novo ritmo que mesclava o samba duro com reggae jamaicano, transformando a música em bandeira política com força suficiente para barganhar cidadania para o negro baiano, chamando atenção para a vitalidade da cultura negra na Bahia (Id.: 21).

\footnotetext{
${ }^{8}$ PESSOA DE CASTRO, Yeda. Falares africanos na Bahia: um vocabulário afro-brasileiro. 2 ed. Rio de Janeiro: Topbooks, 2005, p. 122.

${ }^{9}$ GUERREIRO, Goli. A trama dos tambores: a música afro-pop de Salvador. São Paulo: Editora 34, 2000, p. 33.
} 
A autora conceitua este ritmo musical como um gênero criado por blocos afrocarnavalescos de Salvador, na década de 80 , caracterizado pela apologia ao negro e pela mescla de ritmos sagrados (toques de candomblé) e profanos, resultando do "intercruzamento ideológico entre Bahia, EUA e Jamaica ${ }^{10 \prime}$. Deste modo, o samba-reggae é composto por amplas fontes culturais, além da dimensão política do movimento afro baiano:

\begin{abstract}
Além das recriações estéticas que deram origem ao samba popular urbano, elemento básico do samba-reggae, a segunda pista são as referências internacionais, que vem dos Estados Unidos, da África e da Jamaica e se somam às informações produzidas em Salvador. Esse processo, que está na base da invenção do ritmo, representa a formação de uma "negritude soteropolitana", que se desenhou em meados dos anos 70 e decorre da década de 80 . O movimento de negritude origina-se na tomada de consciência do negro, gerada nos vários países que abrigaram a diáspora africana. Focalizar o panorama internacional do movimento de negritude é fundamental para compreender o sentido e os trunfos da nova musicalidade afro-baiana, que vai ser alimentada por múltiplas referências ${ }^{11}$.
\end{abstract}

As músicas de samba-reggae são ligadas às raízes negras que caracterizam a Bahia e, desta forma, o grupo lexical que compõe as letras destas músicas é composto por termos africanos, assinalando quais as nações de candomblé mais representadas nestas músicas.

O samba, de raiz africana, foi trazido de volta à música e mesclado ao reggae latino e aos instrumentos musicais utilizados nos rituais de candomblé - instrumentos estes de origem africana, considerados objetos sagrados, como o agogô e o atabaque, pois são utilizados nos terreiros para convocar os orixás. O candomblé oferece ao samba-reggae, além dos instrumentos musicais, o caráter de negritude e a preocupação com as raízes negras. Este ritmo tem como precursores os blocos afro llê Aiyê e Malê Debalê, que são blocos de dimensão política, já que fazem parte de movimentos negros.

Guerreiro (2006) afirma que um dos fatores que mais categorizam o samba-reggae é a influência da música jamaicana. Bob Marley se transforma num ícone da música negra, num

\footnotetext{
${ }^{10}$ GUERREIRO, Goli. Samba-reggae, um ritmo atlântico: a invenção do gênero no meio musical de Salvador, Bahia. In: VII Congresso IASPM-AL. ACTAS DEL VII CONGRESO LATINOAMERICANO IASPM - AL. Havana: IASPM- AL, 2006, p. 04.

${ }^{11}$ GUERREIRO, Goli. A trama dos tambores: a música afro-pop de Salvador. São Paulo: Editora 34, 2000 , p. 65.
} 
símbolo da luta pelo anti-racismo, ao representar o movimento étnico-político-religioso conhecido como rastafarianismo. Esse movimento influencia a cultura baiana, de tal modo que pessoas negras passam a usar dreadlocks no cabelo, encontrando no ritmo reggae e na nova estética, uma forma de afirmação negra. O posicionamento político contido nas músicas e na estética de Bob Marley, ou na que lhe representa, faz a causa negra tornar-se internacional.

Outra referência internacional é a música dos Estados Unidos, que influencia o movimento de afirmação negra. A música de James Brown, Jimi Hendrix e o grupo Jackson Five, criam uma novo estilo e um novo modelo de imagem, estimulando a valorização da estética e da cultura negra, por meio do estilo black power. Os jovens brasileiros se apropriaram deste estilo, formando a geração black power, que passa a fazer parte da estética negra de Salvador, na década de 70.

\begin{abstract}
A maior população negro-mestiça do país reinterpreta os pilares do movimento e faz a passagem do black ao afro e do soul ao ijexá. As informações musicais que chegavam a Salvador, a partir dos discos e das imagens de artistas negros norteamericanos, influenciaram o comportamento dos negros baianos ${ }^{12}$.
\end{abstract}

Guerreiro (2006) cita a África como um dos elementos influenciadores na composição do samba-reggae, pois o processo de luta pelo reconhecimento e revalorização das raízes negras impulsionou um retorno à África-mãe e a unificação de povos negros. É nesse cenário histórico apresentado que surge o samba-reggae. Este ritmo musical se apropria do modelo de imagem negra criada nos Estados unidos, de desejo de regressão à África-mãe e, especialmente, do ritmo e da ideologia das músicas de Bob Marley. Todos esses elementos influenciam e motivam a existência de movimentos sociais que reivindicam respeito ao negro - é neste âmbito que a música se inscreve.

O samba-reggae, esse ritmo baiano que conecta elementos jamaicanos, africanos e americanos, tem como componente fundamental o movimento de negritude, pois as letras das músicas desse estilo fazem apologia à cultura negra. Segundo Guerreiro, formulou-se um discurso de caráter afirmativo capaz de dar à música baiana um caráter político-ideológico:

${ }^{12}$ GUERREIRO, Goli. A trama dos tambores: a música afro-pop de Salvador. São Paulo: Editora 34, 2000, p. 87.

Odeere: revista do programa de pós-graduação em Relações Étnicas e Contemporaneidade - UESB. ISSN 2525- 4715. Ano 2, número 3, volume 3, Janeiro - Junho de 2017. 
O que estava em jogo naquele momento era a articulação de um discurso afirmativo, a luta por um melhor posicionamento dos negros na sociedade americana (que emergiu sob os slogans de black power, black is beautiful, entre outros) não passou despercebida aos membros dos blocos afro ${ }^{13}$.

Os blocos afro encontram uma fundamentação política ao investir em pesquisas acerca dos povos e países africanos como meio de mobilizar a comunidade afro-baiana, além de investir em eventos culturais, como em concursos de beleza negra para representar seus blocos carnavalescos.

Guerreiro (2000) diz que o samba-reggae foi uma efervescência musical que, na década de 80, atraiu a atenção da imprensa nacional. Um ritmo que resulta da soma do samba duro com o reggae, deu uma força ainda maior aos movimentos afro-baianos, haja vista que as letras das músicas cantadas por blocos afro traziam conteúdo político.

A estética afro-baiana representada pelos blocos está pautada no hibridismo cultural que caracteriza o samba-reggae: uma mistura de cores da Jamaica com vários tipos de cabelo, a saber, black power e dreads, em referência a ídolos da música negra. Outra forma de identificação negra, além da estética, é a valorização e uso dos elementos do candomblé como, por exemplo, os instrumentos musicais, marcando, deste modo, a relação do ritmo em questão com o sagrado:

\begin{abstract}
A percussão, tocada nos atabaques dos terreiros, é a base da musicalidade dos blocos. Além dos ritmos, o recurso vocal também encontra paralelos nos rituais sagrados. A técnica responsorial utilizada nos cultos do candomblé, que consiste em uma pergunta puxada pelo solista e respondida pelo coro e/ou pelos atabaques foi apropriada pela produção musical dos blocos afro e inspirou a estrutura de várias canções, onde a voz do cantor/cantora aparece antes do som dos tambores (repiques, taróis, surdos), servindo para puxar bateria (Id.: 51).
\end{abstract}

Os aportes lexicais africanos utilizados nas letras das músicas são fatores importantes na construção das mensagens de africanidade, posto que remetem a raízes africanas.

Guerreiro, ao discutir expressão corporal, afirma que a dança afro é uma reinvenção da dança dos orixás. Realizada a partir de movimentos rasteiros, ela também é expressão de culto aos orixás.

\footnotetext{
${ }^{13}$ GUERREIRO, Goli. A trama dos tambores: a música afro-pop de Salvador. São Paulo: Editora 34, 2000, p. 88.
} 
Os relatos históricos que se reportam ao fim do século XIX e início do século XX apontam a música como parte integrante do cotidiano dos negros e a presença do candomblé observável no dia-a-dia, nos cantos (onde ofereciam seus serviços), nas lojas (onde habitavam coletivamente), ou nos terreiros (onde cultuavam os seus deuses). Além de atividades religiosas, ligadas ao candomblé, os negros elaboravam ainda uma série de divertimentos que também envolvia estas artes (Id.:67).

Além dos instrumentos musicais característicos do candomblé, a música afro-baiana passou a incorporar instrumentos eletrônicos, como estratégia para ganhar mais espaço na mídia. Acomodando novos sons, o samba-reggae se renova esteticamente, segundo Guerreiro:

Os grupos afro aderiram à mescla das sonoridades dos instrumentos percussivos e harmônicos, o que implicou uma redução do número de tambores da bateria. $\mathrm{O}$ volume do som dos tambores abafa naturalmente a sonoridade dos instrumentos harmônicos utilizados pelo samba-reggae, como a guitarra, o baixo, o teclado, o sax. Capturar os diferentes instrumentos através de equipamento eletrônico é, na verdade, a única maneira de conciliar universos sonoros tão distintos (Ibdem).

Essa renovação estética, a qual a autora se refere, proporcionou a grupos como Olodum e Ara Ketu, uma maior repercussão nacional, porém, outros grupos, como o llê Aiyê, Male Debalê, são mais conservadores e não se filiaram a essa renovação. samba-reggae é um dos estilos musicais mais difundidos no Brasil, ganhando notoriedade na década de 1990, com as cantoras Margareth Menezes e Daniela Mercury, com as composições de Carlinhos Brow, Gerônimo (que se considera pioneiro), Jorge Zarath, entre outros.

\section{Análise de algumas composições}

As músicas de samba-reggae apresentam em seu repertório um vasto vocabulário de origem africana relacionado, em sua maioria, ao candomblé, o que reitera o vínculo do samba reggae com o sagrado. A seguir, a análise das composições mostra que a cultura afro é a essência da composição deste estilo musical. Os quadros exibidos a seguir foram organizados, segundo os estudos de Pessoa de Castro (2005) e Schlesinger (1920). 


\section{Maimbé Dandá, composição de Carlinhos Brown}

Corre Cosme chegou

Doum Alabá

Damião Jaçanã

Pra levar e deixar

Alegria de erê

É ver gente sambar

Meu look laquê

Mandei cachear

Me alise pra ver

Meu forte é beijar

Vou cantar maimbê

Pra você se acabar

Maimbê, Maimbê, Dandá

Maimbê, Maimbê, Dandá

Maimbê, Maimbê, Dandá

Maimbê, Maimbê, Dandá

Maimbê, Maimbê, Dandá

Maimbê, Maimbê, Dandá

Maimbê, Maimbê, Dandá
Maimbê, Maimbê, Dandá

Zum, zum, zum, zum, zum, baba

Zum, zum, baba, zum, zum, baba

Traga a avenida com você

Tava esperando Maimbê

Zum, zum, zum, zum, zum, Baba

Zum, zum, baba, zum, zum, Baba

Corre Cosme chegou

Doum Alabá

Damião Jaçanã

Pra levar e deixar

Alegria de erê

É ver gente sambar

Oiá eparrêi me ensine a espiar

Com os olhos de quem

Me cega de amar

Vou cantar maimbê, pra você se acabar

\begin{tabular}{|l|l|l|}
\hline TERMO & ORIGEM & ACEPÇÃO \\
\hline Cosme & Formação brasileira & Espírito infantil \\
\hline Doum & Iorubá & Irmão de Cosme e Damião \\
\hline Alabá & Iorubá & Irmão de Cosme e Damião \\
\hline Jaçanã & Tupi & Ave da Afam \\
\hline Erê & loruba & Entidade infantil \\
\hline Maimbê & Não encontrado & \\
\hline Dandá & Quicongo/quimbundo & Título de nobreza \\
\hline Zum zum & Quicongo/ quimbundo & Fazer barulho \\
\hline Oiá & lorubá & lansã \\
\hline Eparrei & lorubá & Saudação à lansã \\
\hline Baba & Quicongo/quimbundo & Pai de santo \\
\hline
\end{tabular}

Quadro 01: Termos de origem africana depreendidos da música Maimbé Dandá, de autoria de Carlinhos Brown. 
O início da música Maimbé Dandá, de autoria de Carlinhos Brow (2008), anuncia a chegada de Cosme - um dos gêmeos Cosme e Damião, cultuados pelo cristianismo católico como santos mártires que viveram entre os séculos III e IV da era cristã, foram gêmeos e exerceram a profissão da medicina. Pelo processo de sincretismo, foram associados aos Ibejis (divindades gêmeas) ${ }^{14}$, que representam espíritos infantis, geralmente cultuados por iniciados, que passam por um processo iniciático de reclusão no terreiro e por rituais típicos como banho e raspagem de cabeça, segundo Pessoa de Castro (2005) - e a chegada dos seus irmãos Doum, primeiro filho após os gêmeos, que é representado na imagem de Cosme em tamanho reduzido, e Alabá, o segundo filho após os gêmeos, formando par com Doum.

O samba de raiz negro-africana é colocado na música como uma forma de oferecer alegria a uma das entidades religiosas, o erê. Este é uma entidade infantil que o iniciado recebe ao sair do transe de possessão dos santos e que faz com que ele se comporte como criança. Neste momento, a fala do iniciado é marcada pelo uso de palavras de baixo calão, em sua maioria de origem banto, como afirma Pessoa de Castro:

Entidades infantis que o iniciado costuma receber geralmente ao sair do transe de possessão dos santos. Sua fala é quase um tatibitate, por isso considerada de qualidade inferior, primária, associada ao uso de crianças em fase de socialização. Não obstante, ela pode ser acompanhada de gestos chulos, com emprego demasiado de "benditos palavrões", ou seja, determinadas palavras considerada abusivas em português carregadas de conotações obscenas, embora ditas e aceitas em tom jocoso e caricato, sob a forma de humor cerimonial ${ }^{15}$.

O refrão da música faz uma repetição dos nomes Maimbé (significado e origem não encontrados) Dandá, que é um dos nomes de lemanjá, orixá do mar, aquele que protege e conduz seus devotos, e zunzum, de origem banto, que é termo conhecido na linguagem popular como 'fazer barulho'.

Na última estrofe da canção, o compositor invoca, por meio da palavra Oiá,

\footnotetext{
${ }^{14}$ Sobre esse processo de sincretismo e o modo como ele é apresentado na Bahia, pela mídia, ver: SANTOS, Emilena Sousa dos. Era uma vez Êres. In Nures (Núcleo de Estudos Religião e Sociedade), n. 16, Set-Dez, Pontifícia Universidade Católica - SP, 2010.

${ }^{15}$ PESSOA DE CASTRO, Yeda. Falares africanos na Bahia: um vocabulário afro-brasileiro. 2 ed. Rio de Janeiro: Topbooks, 2005, p. 89.
}

Odeere: revista do programa de pós-graduação em Relações Étnicas e Contemporaneidade - UESB. ISSN 2525- 4715. Ano 2, número 3, volume 3, Janeiro - Junho de 2017. 
lansã, o orixá do trovão. Esta divindade feminina representa a coragem, é a deusa do rio Niger, na Nigéria. O verso da canção diz Oiá eparrei: o compositor invoca Oiá, nome de lansã menina. Esta é uma das mulheres de Xangô, considerado o orixá dos raios, herói do povo iorubá. O refrão da música faz uma saudação a lansã, através do termo eparrei; no entanto, observa-se uma inversão na ordem das palavras, pois, em iorubá costuma-se dizer eparrei Oiá, ou seja, primeiro se pronuncia eparrei, a saudação, depois Oiá, o nome do orixá. Acredita-se que a inversão foi feita para manter a harmonia sonora.

\section{Toté de maiangá, composição de Gerônimo, Saul Barbosa e Tony Osanah}

Vinha passando pela mata escura

No bate folha ouvi uma canção

Que é pro santo

Poder sair da aldeia

Para chamar o orixá dessa nação

Com o balanço do mar eu vim

Com o balanço do mar eu vou

$E$ a enquisse que vovó me ensinou

Eu vou cantar que é pra chamar o meu

amor

Chego lá, chego lá

Toté toté de maiangá

Maiangôlê

Toté toté de maiangá

Maiangôlê

Toté toté de maiangá

Maiangôlê
Quem é o cavalheiro

Que vem de Aruanda

É oxossi em seu cavalo

E seu chapéu de banda

Quem é o cavalheiro

Que vem de Aruanda

É oxossi em seu cavalo

E seu chapéu de banda

Toté toté de maiangá

Maiangôlê

Toté toté de maiangá

Maiangôlê

Toté toté de maiangá

Maiangôlê...

\begin{tabular}{|l|l|l|}
\hline TERMO & ORIGEM & ACEPÇÃO \\
\hline Orixá & lorubá & Designação genérica para \\
\hline
\end{tabular}

Odeere: revista do programa de pós-graduação em Relações Étnicas e Contemporaneidade - UESB. ISSN 2525- 4715. Ano 2, número 3, volume 3, Janeiro - Junho de 2017. 


\begin{tabular}{|l|l|l|}
\hline & & divindades \\
\hline Inquice & $\begin{array}{l}\text { Quicongo/quimbumdo } \\
\text { umbundo }\end{array}$ & $\begin{array}{l}\text { Designação genérica } \\
\text { para entidades }\end{array}$ \\
\hline Vovó & Formação brasileira & $\begin{array}{l}\text { Escravo } \\
\text { africano }\end{array}$ \\
\hline Toté & Quicongo & Cântico de louvor \\
\hline Maiangá & Quicongo/quimbundo & Banho em riacho \\
\hline Maiangolê & Não encontrado & África mítica \\
\hline Aruanda & Banto & Orixá da caça \\
\hline Oxóssi & lorubá & lemanjá \\
\hline Coquê & lorubá & $\begin{array}{l}\text { Faixa para tapar os olhos } \\
\text { durante a iniciação }\end{array}$ \\
\hline Banda & Não encontrado & denang \\
\hline
\end{tabular}

Quadro 02: Termos de origem africana presentes na música Toté de Maiangá, de autoria de Saul Barbosa, Gerônimo e Tony Osanah.

Esta música, composta por Saul Barbosa, Gerônimo e Tony Osanah (2008), traz em seu título, palavras de origem africana, como toté, termo utilizado em cânticos de louvor às divindades, que, unido ao termo maiangá, faz um convite a banhar-se em um riacho próximo ao terreiro e louvar os orixás. O compositor coloca que todas as canções cantadas no terreiro são para convocar as divindades da nação iorubá, denominadas orixás, e que todas estas canções foram ensinadas por uma Preta-Velha, ou seja, uma negra anciã, uma ancestral africana, também tratada como vovó, que deixou ensinamentos ao povo de santo.

Após o refrão da música em que há uma saudação e louvor ao orixá, por meio da expressão Toté de Maiangá, há um questionamento sobre o surgimento de um cavaleiro de origem Aruanda. Este, que vem montado em um cavalo, é o orixá da caça, o protetor dos caçadores, conhecido como Oxóssi, que no catolicismo é equivalente a São Jorge. Sua origem remete a Aruanda, sua região-mãe.

\section{Dandalunda, composição de Carlinhos Brown}

Bem pertinho da entrada do Gueto Um terreiro de Angola e Ketu Mãe Maiamba que comanda o centro Dona Oxum dançando Oxóssi no tempo
Lá em cima do tamarineiro Marinha da pipoca ajoelha Em janeiro, no dia primeiro Desce o dono do terreiro 
Coquê

Dandalunda, maimbanda coquê

Dandalunda, maimbanda coquê

Dandalunda, maimbanda coquê

Dandalunda, maimbanda coquê

Coquê

Seu Zumbi é santo sim que eu sei

Caxixi, agdavi, capoeira

Cãs de batuque e toque na mesa

Linda, Santa lansã da pureza

Vira fogo atraca, atraca se chegue

Vi Nanã dentro da mata do Jêje
Brasa acesa na pisada do frevo

Arrepia o corpo inteiro

Coquê....

Dandalunda, maimbanda coquê

Dandalunda paira na beira

Dandalunda da cachoeira

Dandalunda paz e água fresca

Dandalunda doura dendê

Coquê...

\begin{tabular}{|l|l|l|}
\hline TERMO & ORIGEM & ACEPÇÃO \\
\hline Ketu/queto & lorubá & $\begin{array}{l}\text { Designação dada aos } \\
\text { africanos de língua iorubá }\end{array}$ \\
\hline Angola & Quimbundo & País africano \\
\hline Maiamba & Não encontrado & Não encontrado \\
\hline Oxum & lorubá & Orixá das aguas doces \\
\hline Oxóssi & lorubá & Orixá da caça \\
\hline Coquê & lorubá & lemanjá \\
\hline Dandalunda & Quicongo/quimbundo & Divindade das aguas \\
\hline Maimbanda & Não encontrado & Líder dos palmares \\
\hline Zumbi & Quicongo & $\begin{array}{l}\text { Saco de palha para tocar } \\
\text { berimbau }\end{array}$ \\
\hline Caxixi & Quicongo/quimbundo & Baqueta de percussão \\
\hline Aguidavi & Fon & Ataque e defesa \\
\hline Capoeira & Formação brasileira & Ritmo \\
\hline Batuque & Formação brasileira & Orixá do fogo \\
\hline lansã & lorubá & $\begin{array}{l}\text { Dinvidades das aguas } \\
\text { paradas }\end{array}$ \\
\hline Nanã & Fon & $\begin{array}{l}\text { Designação dada aos } \\
\text { africanos de língua ewe- } \\
\text { fon }\end{array}$ \\
\hline Jeje & Fon & Óleo da palmeira \\
\hline Dendê & Quicongo/quimbundo & \\
\hline
\end{tabular}

Quadro 03: termos de origem africana presentes na música Dandalunda, de autoria de Carlinhos Brown.

A canção Dandalunda, composta por Carlinhos Brow (2008), começa com a exaltação das duas nações de candomblé, a congo-angola e a nagô-queto, que são "nações 
africanas" (grupos de escravos) que se instalaram em Salvador, falantes, respectivamente, das línguas do grupo banto e da língua iorubá. Os terreiros são comandados por mãe Maiamba, que convoca Oxum e Oxóssi.

O compositor marca, nesta música, a importância do dia primeiro de janeiro para o povo de santo. Neste dia, fazem-se oferendas e louvores aos feitos de lemanjá, nomeada aqui como Coquê e Dandalunda, que são as palavras que compõe o refrão da música. O rei dos palmares, Zumbi, de origem banto, vem representado como um santo, por ter lutado pela liberdade do seu povo ao formar o quilombo dos palmares.

Os sons dos instrumentos musicais citados nesta canção, caxixi e agdavi, são, respectivamente, um saquinho de palha utilizado para tocar o berimbau da capoeira, arte de ataque e defesa criado pelos escravos congo-angola, nas senzalas onde viviam, e a baqueta, utilizada para tocar os tambores considerados sagrados nos rituais de casas de batuque, ou seja, nos terreiros de candomblé, onde lansã é exaltada como santa por representar a pureza de um dos elementos da natureza, o fogo.

Por meio da letra desta música, o compositor faz uma exaltação à mãe de todos os orixás, a ancestral Nanã, da nação jeje, comunidade africana do grupo linguístico ewe-fon, orixá que é visto dentro da mata, lugar onde se enterra as oferendas feitas aos orixás.

lemanjá é sinônimo de paz, sendo chamada, nesta música, de duas formas diferentes: Dandalunda, termo pertencente ao grupo lingüístico banto, falado nas línguas kicongo e kimbundo, que remete a nação congo-angola, e Coquê, termo de procedência iorubá, que remete à nação nagô-queto. A letra da música une as duas nações de candomblé pelas diferentes nomeações dadas à Mãe d'agua, lemanjá, sendo que a palavra Dandalunda pode também fazer referência a Oxum, mãe das águas doces.

\section{Guerrilheiros da Jamaica, compositor desconhecido}

Mama, mama, África

Mama, mama, África

Mama, mama, África, ié, ié
Rumpilé rompeu tambô, ô, ô Jazz e blues canções nagô ljexá

Quem ouviu não vacilou 
Se tocou

Africanizado está, á, á, á

E a galera na beira do mar

Muzenza, ô, ô, ô

Guerrilheiros ô, ô, ô

Mama, mama, África

Mama, mama, África

Mama, mama, África, ié, ié

Bob Marley semeou, ô, ô, ô, ô
E o reggae se espalhou

Muzenza

Difundiu em Salvador

Se tocou

Jamaicado está, á, á, á

E a galera na beira do mar

Muzenza, ô, ô, ô

Guerrilheiros ô, ô, ô

\begin{tabular}{|l|l|l|}
\hline TERMO & ORIGEM & ACEPÇÃO \\
\hline Rumpilé & Fon & Instrumento musical \\
\hline Nagô & lorubá & $\begin{array}{l}\text { Designação dada aos } \\
\text { africanos de língua iorubá }\end{array}$ \\
\hline ljexá & lorubá & Nação de candomblé \\
\hline Muzenza & Quicongo/quimbundo & Noviço \\
\hline
\end{tabular}

Quadro 04: Termos de origem africana presentes na música Guerrilheiros da Jamaica, de autoria desconhecida.

As primeiras estrofes desta música explicitam que o movimento de afirmação negra vem sendo incorporado pelos blocos afro. O sentido desta letra é construído a partir do uso de termos de origem africana, numa apologia ao povo de santo e a Bob Marley. O som do rumpilé, instrumento musical sagrado utilizado nos terreiros de candomblé, proporciona o surgimento de um novo som influenciado por outros ritmos, como o jazz e o blues: o som do samba-reggae.

Os ritmos jazz e blues são participantes nas músicas do ijexá nagô, que é uma antiga nação de povos de origem nagô-queto, falantes de iorubá, a qual se instalou em Salvador, formando uma nação de candomblé. Essa formação sócio histórica, aliada aos ritmos musicais, como diz a canção, é o que caracteriza a música afro: "Rumpilé rompeu o tambô / jazz e blues canções nagô/ ijexá/ quem ouviu não vacilou/ se tocou/ africanizado está". Nestas nações, o ijexá, ou seja, o toque, o ritmo produzido, é para louvar Oxum.

Nessa letra, há termos de origem banto e de origem iorubá. Ao chamar os iniciados, o compositor utiliza a palavra muzenza, conhecida nas línguas do grupo banto, 
como 'noviço'. Aqui, o compositor não se preocupa em priorizar uma nação de candomblé, congo ou nagô, ele exalta as duas nações, no refrão, ao colocar a África como mãe de todas as nações. Após o refrão, Bob Marley é reverenciado como o grande propulsor do reggae, como aquele que semeou um estilo musical que se espalhou e inspirou um novo ritmo em Salvador, o samba-reggae: "Bob Marley semeou / E o reggae se espalhou/ Muzenza/ Difundiu em Salvador/ se tocou/ Jamaicado está".

\section{Raça negra, composição de Jorge Zarath}

O grito da terra se expande por todo o

Raça negra, raça negra universo

No verso da mão calejada que afaga o rebento

Raça negra, raça negra

Sou erê, sou mandinga, sou manhã Sou dendê, afilhada de Yansã

O amor relampeja quebrando a semente da guerra

Sagrada é a força da Terra brilhando num só pensamento

Sou café, cana-verde, que beleza

Raça negra!

Sou de paz, sou axé, sou natureza

Olorum mandou botar

Um presente pra lemanjá

Raça negra, naça negra

Colocar no mar do amor

Raça negra, Raça negra

Pra saudar seu ganzuá

Mãe Oxum me batizou

Aiá, aiá, aiá...

Aiê, aiê, aiá, aiê, aiê...

Com a benção de Oxalá

É felicidade é com, oh yeah

\begin{tabular}{|l|l|l|}
\hline TERMO & ORIGEM & ACEPÇÃO \\
\hline Olorum & lorubá & Deus supremo \\
\hline Iemanjá & lorubá & Orixá do mar \\
\hline Ganzuá & Quicongo/quimbundo & Casa de candomblé \\
\hline Oxum & lorubá & Orixá das aguas doces \\
\hline Oxalá & lorubá & Divindade suprema \\
\hline Erê & lorubá & Entidade infantil \\
\hline Mandinga & Quicongo/quimbundo & Feitiço \\
\hline
\end{tabular}

Odeere: revista do programa de pós-graduação em Relações Étnicas e Contemporaneidade - UESB. ISSN 2525- 4715. Ano 2, número 3, volume 3, Janeiro - Junho de 2017. 


\begin{tabular}{|l|l|l|}
\hline Dendê & Quicongo/quimbundo & Óleo da palmeira \\
\hline lansã & Fon & Orixá do fogo \\
\hline Axé & Fon/ ioruba & Objeto sagrado \\
\hline Aia & & $\begin{array}{l}\text { Tratamento dado a } \\
\text { solteiras }\end{array}$ \\
\hline Aiê & lorubá & Mundo \\
\hline
\end{tabular}

Quadro 05: Termos de origem africana presentes na música Raça Negra, de autoria de Jorge Zarath.

Jorge Zarath (2008), ao compor a música Raça Negra, demonstra a tendência do estilo samba-reggae em levar o religioso às letras das músicas, pois, logo no início da letra, ele expressa a devoção à lemanjá. Segundo esta letra, todos os presentes dados a ela são jogados ao mar, a pedido de Olorum, Deus supremo, saudando o seu ganzuá, palavra de origem banto que significa 'casa de candomblé', já que o mar, no que se refere a devoção a lemanjá, constitui um lugar de reza, este é o seu ganzuá, isto é, a sua casa: “Olorum mandou botar/ um presente a lemanjá/ colocar no mar do amor/ pra saudar seu ganzuá".

O compositor, após falar de lemanjá, fala sobre o seu próprio batizado, processo de iniciação no candomblé; sua madrinha é Oxum, orixá das águas doces, que o batizou com a benção de Oxalá, o pai de todos os orixás.

O compositor reconhece a cultura negra e se coloca como participante dos rituais de candomblé, como, por exemplo, no ritual de possessão, ao se denominar 'Erê', entidade infantil, e ao se dizer mandinga, palavra de origem banto, que significa impedir através de feitiço, prática litúrgica do candomblé: "Sou erê, sou mandinga, sou manhã, sou dendê, afilhada de lansã”. Nesta estrofe, o compositor revela sua consciência em relação à negritude, ao se identificar como afro-descendente, que herdou a cor da pele e a religião dos seus descendentes.

\section{Salvador não inerte, composição de Bobôco e Beto Jamaica}

Olodum negro elite é negritude

Deslumbrante por ter magnitude

E leva no canto toda massa

Que vem para a praça se agitar

Salvador se mostra mais alerta
Com o Bloco Olodum a cantar

Lê lê lê ô

Lê lê lê ô

Ê baêa

Odeere: revista do programa de pós-graduação em Relações Étnicas e Contemporaneidade - UESB. ISSN 2525- 4715. Ano 2, número 3, volume 3, Janeiro - Junho de 2017. 
Ê baêa

Aganjú, Alujá, muito axé

Canta o povo de origem nagô

O seu corpo não fica mais inerte

Que o Afro-Olodum já cantou
Ê baêa

Ê baêa

Aganjú, alujá, muito axé

Canta um povo de origem nagô

O seu corpo não fica mais inerte

Que o Bloco Olodum já cantou

Lê lê lê ô

Lê lê lê ô

\begin{tabular}{|l|l|l|}
\hline TERMO & ORIGEM & ACEPÇÃO \\
\hline Aganjú & Iorubá & Xangô \\
\hline Alujá & Iorubá & Toque cerimonial \\
\hline Axé & Fon/ ioruba & Objeto sagrado \\
\hline Ijexá & Iorubá & Nação de candomblé \\
\hline Muzenza & Quicongo/quimbundo & Noviço \\
\hline
\end{tabular}

Quadro 06: termos de origem africana presentes na música Salvador não inerte, de autoria de Bobôco e Beto Jamaica.

Para Guerreiro (2000), o bloco afro Olodum passou por um processo de renovação no início da década de 80 , transformando-se em grupo cultural que realiza projetos sociais para a comunidade carente e cria músicas com contornos de movimento social.

Quanto mais se impregnava de um discurso anti-racista acadêmico, mais se constituía enquanto uma intelectualidade orgânica, de grande peso no movimento baiano, dedicada a uma pesquisa histórico-antropológica que visa o resgate da ancestralidade negra culta, apontando dessa maneira para uma "África científica" ${ }^{16 " .}$

Obedecendo a essa estética, o Olodum é um grupo de música afro-brasileira que faz transparecer, em suas letras, a preocupação com questões relativas ao negro; o seu enredo tem um tom político, social e suas composições despertam o interesse pela cultura afro-brasileira. $\mathrm{O}$ título da canção, Salvador não inerte, já propõe este movimento de conscientização e de valorização de aspectos que envolvem a causa negra, como, por exemplo, a religiosidade e a valorização das línguas africanas, que inclusive é percebido na denominação do grupo, haja vista

\footnotetext{
${ }^{16}$ GUERREIRO, Goli. A trama dos tambores: a música afro-pop de Salvador. São Paulo: Editora 34, 2000 , p. 43.
}

Odeere: revista do programa de pós-graduação em Relações Étnicas e Contemporaneidade - UESB. ISSN 2525- 4715. Ano 2, número 3, volume 3, Janeiro - Junho de 2017. 
que o termo Olodum, redução de Olodumaré, significa 'Deus dos Deuses', a maior de todas as divindades.

A letra dessa música aborda a chegada do Bloco Olodum, propõe este movimento de reunião de povos afro, do povo nagô, para louvar o herói do povo iorubá, o orixá Xangô, nomeado aqui como aganjú, cujo alujá, toque cerimonial, é especial.

\section{Considerações Finais}

A compreensão de aspectos da cultura baiana perpassa pelo conhecimento de determinados traços culturais de raízes africanas. No que toca ao universo musical baiano, à leitura de algumas letras de músicas do ritmo Samba reggae, fez-se necessário uma pesquisa sobre grupos africanos que povoaram Salvador, para que, desta forma, assinalássemos as línguas por eles faladas e as nações de candomblé formadas na Bahia. Deste modo, seria possível ler as letras e apontar sua relação com o afro linguístico e o afro religioso.

As composições analisadas apresentam termos de origem diversificada: banto, iorubá e em poucos casos fon, porém a grande incidência de termos de origem africana é de origem nagô. Considerando que a fixação de escravos falantes de iorubá em Salvador é mais recente que a de povos bantos, apontamos, com base na análise, que as nações de candomblé mais representadas nessas composições são as nações nagô-queto, haja vista que a maior incidência de termos é de origem iorubá.

Faz-se imprescindível afirmar a relação que a música, enquanto expressão artístico cultural, estabelece com o religioso. Em nossas análises percebemos que as composições se relacionam ao sagrado, ao reverenciar as divindades afro religiosas, e reitera a sua função político social, posto que através da linguagem e dos instrumentos musicais, o samba reggae estabelece uma conexão com o simbólico, afirmando-se como um ritmo político afro-baiano. 


\section{Referências Bibliográficas}

ARAÚJO, Silvana Silva de Farias; ARAÚJO, Jean Marcel de Oliveira. A formação sócio-histórica do português do brasil: contribuições do recôncavo baiano. In: Cadernos de Letras da UFF - Dossiê: Difusão da língua portuguesa. Rio de Janeiro: UFF, n. 39, 2009, (p. 95-116).

DIÉGUES JÚNIOR, Manuel. Etnias e culturas no Brasil. Rio de Janeiro: Biblioteca do Exército, 1980.

GUERREIRO, Goli. A trama dos tambores: a música afro-pop de Salvador. São Paulo: Editora 34, 2000.

GUERREIRO, Goli. Samba-reggae, um ritmo atlântico: a invenção do gênero no meio musical de Salvador, Bahia. In: VII Congresso IASPM-AL. ACTAS DEL VII CONGRESO LATINOAMERICANO IASPM - AL. Havana: IASPM- AL, 2006.

PESSOA DE CASTRO, Yeda. Falares africanos na Bahia: um vocabulário afro-brasileiro. 2 ed. Rio de Janeiro: Topbooks, 2005.

SANTOS, Emilena Sousa dos. Era uma vez Êres. In: Nures (Núcleo de Estudos Religião e Sociedade). São Paulo: Pontifícia Universidade Católica, n. 16, Set-Dez, 2010.

SCHLESINGER, Hugo; PORTO, Humberto. Dicionário enciclopédico das religiões. Petrópolis, RJ: Vozes, 1995.

VERGER, Pierre Fatumbi. Orixás. 4 ed. São Paulo: Corrupio Edições e Promoções Culturais, 1992.

VILA, Martinho da. A influência africana na música popular. In: Chaves, Rita; Secco, Carmem; Macedo, Tânia (org.). Brasil / Àfrica: Como se o mar fosse mentira. São Paulo: UNESP, 2007 (p. 2527).

\section{Referências eletrônicas}

BARBOSA, Saul; OSANAH, Tony; Gerônimo. Toté de Maiangá. Disponível em: <http://vagalume.uol.com.br/margarreth-menezes/tote-de-maianga.html>. Acesso em 2017.

BROWN, Carlinhos. Dandalunda. Disponível em: <http://vagalume.uol.com.br/margarrethmenezes/dandalunda.html $>$. Acesso em 2008.

BROWN, Carlinhos. Maimbê Dandá. Disponível em: <http://vagalume.uol.com.br/margarrethmenezes/maimbe-danda.html>. Acesso em 2017. 
COMPOSITOR DESCONHECIDO. Guerrilheiros da Jamaica. Disponível em: $<$ http://vagalume.uol.com.br/margarreth-menezes/guerrilheiros-da-jamaica.html>. Acesso em 2017.

JAMAICA, Beto; Bobôco. Salvador não inerte. Disponível em: $<$ http://vagalume.uol.com.br/margarreth-menezes/salvador-nao-inerte.html>. Acesso em 2017.

ZARATH, Jorge. Raça Negra. Disponível em: <http://vagalume.uol.com.br/margarrethmenezes/raca-negra.html>. Acesso em 2017.

Roberta Rosa Portugal: Professora Assistente na Universidade Estadual da Paraíba, ministro disciplinas no curso de Letras/Espanhol. Graduação em Letras com Língua Espanhola pela Universidade Estadual de Feira de Santana (2008) e mestrado em Desenho, Cultura e Interatividade (2011), nesta mesma universidade. Área de conhecimento em linguagem visual.

Artigo recebido para publicação em: Maio de 2017.

Artigo aprovado para publicação em: Junho de 2017.

Odeere: revista do programa de pós-graduação em Relações Étnicas e Contemporaneidade - UESB. ISSN 2525- 4715. Ano 2, número 3, volume 3, Janeiro - Junho de 2017. 